ISSN: 2302-8556

E-Jurnal Akuntansi Universitas Udayana

Vol.25.3.Desember (2018): 1826 - 1855

DOI: https://doi.org/10.24843/EJA.2018.v25.i03.p08

\title{
Pengaruh Time Budget Pressure, Locus of Control, Task Complexity, dan Turnover Intention pada Dysfunctional Audit Behavior
}

\section{Margaretta Hana Arsantini ${ }^{1}$ I Dewa Nyoman Wiratmaja ${ }^{2}$}

\author{
${ }^{1}$ Fakultas Ekonomi dan Bisnis Universitas Udayana (Unud), Bali, Indonesia \\ email: margarettahana02@gmail.com/Telp: 0819372738281 \\ ${ }^{2}$ Fakultas Ekonomi dan Bisnis Universitas Udayana (Unud), Bali, Indonesia
}

\begin{abstract}
ABSTRAK
Penelitian ini bertujuan untuk mengetahui pengaruh time budget pressure, locus of control, task complexity, dan turnover intention pada dysfunctional audit behavior. Pengambilan sampel dalam penelitian ini dilakukan secara non probability sampling, yaitu dengan menggunakan pendekatan purposive sampling yakni sebanyak 78 sampel. Metode pengumpulan data untuk penelitian ini adalah dengan menggunakan metode survey dengan kuesioner.Teknik analisis yang digunakan pada penelitian ini menggunakan regresi liniear berganda yang digunakan untuk mengetahui pengaruh variabel bebas pada variabel terikat. Berdasarkan hasil analisis dan pembahasan hasil penelitiantime budget pressure, task complexity, dan turnover intention memiliki pengaruh positif pada dysfunctional audit behavior. Sedangkan, locus of control memiliki pengaruh negatif pada dysfunctional audit behavior
\end{abstract}

Kata Kunci: time budget pressure, locus of control, task complexity, turnover intention, dysfunctional audit behavior

\section{ABSTRACT}

This study aims to determine the effect of time budget pressure, locus of control, task complexity, and turnover intention on dysfunctional audit behavior. Sampling in this study was conducted in non-probability sampling, namely by using a purposive sampling approach that is as much as 78 samples. The method of data collection for this study is to use survey methods with questionnaires. The analysis technique used in this study uses multiple linear regression used to determine the influence of independent variables on the dependent variable. Based on the results of the analysis and discussion of the results of the research budget budget pressure, task complexity, and turnover intention have a positive influence on dysfunctional audit behavior. Whereas, locus of control has a negative influence on dysfunctional audit behavior.

Keywords: time budget pressure, locus of control, task complexity, turnover intention, dysfunctional audit behavior.

\section{PENDAHULUAN}

Perkembangan dunia usaha di Indonesia yang semakin meningkat pasti akan dibarengi dengan meningkatnya kegiatan usahanya. Peningkatan yang dimaksud 
tentunya disertai dengan semakin kompleksnya kegiatan perusahaan yang ujungujungnya menimbulkan persaingan dalam dunia usaha. Saat ini perusahaanperusahaan yang sudah go public diwajibkan untuk memberikan informasi yang jelas mengenai aktivitas bisnis serta keuangannya ke bursa.

Sejalan dengan hal tersebut, maka kebutuhan jasa akuntan publik pun semakin meningkat. Peran akuntan publik menjadi sangat penting bagi sebuah perusahaan, terutama dalam upaya memberikan keyakinan bahwa laporan keuangan yang disajikan oleh menajemen bebas dari salah saji material. Kantor Akuntan Publik (KAP) merupakan suatu bentuk organisasi akuntan publik yang memperoleh izin sesuai dengan peraturan perundang-undangan yang berusaha di bidang pemberian jasa profesional dalam praktik akuntan publik berupa jasa audit operasional, audit kepatuhan, dan audit laporan keuangan (Arens \& Loebbeck, 2003).

Akuntan publik dalam melaksanakan proses audit wajib berpedoman pada Standar Profesional Akuntan Publik (SPAP) yang terdiri atas standar umum, standar pekerjaan lapangan, dan standar pelaporan pertama, kedua, ketiga, keempat. Tujuan audit adalah untuk mengurangi asimetri informasi, serta auditor eksternal memiliki peran untuk menunjukkan apakah dalam pelaporan keuangan telah disusun oleh pihak internal sesuai dengan prosedur dan memastikan kesalahan perlaporannya terbatas (Chiang \& Lin, 2012). (Nasrullah, Margono, \& Solimun, 2013) memaparkan untuk menghasilkan kinerja yang memuaskan seorang auditor harus memiliki sikap yang jujur dan bertanggung jawab dalam melaporkan hasil audit laporan keuangan 
ISSN: 2302-8556

E-Jurnal Akuntansi Universitas Udayana

Vol.25.3.Desember (2018): 1826 - 1855

akuntansi. Serta memahami Kode Etik Profesi Akuntan Publik sebagai panduan utama yang wajib dipahami dan dipatuhi oleh auditor untuk memenuhi tanggung jawab profesional mereka dalam pengauditan laporan keuangan dan menjaga kualitas audit yang dihasilkan (Halim, 2015).

Auditor yang berkompeten dan independen diharapkan dapat menghasikan kualitas audit yang tinggi (Gabrini, 2013). Kualitas audit dapat membangun kredibilitas informasi dan kualitas informasi pelaporan keuangan yang juga membantu pengguna memiliki informasi yang berguna (Chanawongse, Kasom, Poonpol, Parnsiri, \& Nuttavong, 2011). Opini audit yang dikeluarkan auditor berpengaruh dalam menyatakan keyakinan yang memadai atas keandalan laporan keuangan sehingga dapat meningkatkan kepercayaan publik (Hosseinniakani, Inacio, \& Mota, 2014). Opini auditor akan dapat merugikan ketika auditor tidak bekerja sesuai standar yang berlaku (Kangarlouei \& Jabbarzadeh, 2013).

Profesionalisme akuntan publik, salah satunya diwujudkan dalam bentuk menghindari perilaku menyimpang dalam audit. Perilaku menyimpang yang dimaksud adalah perilaku menyimpang yang dilakukan oleh seorang auditor dalam bentuk manipulasi, kecurangan ataupun penyimpangan terhadap standar audit. Manipulasi atau kecurangan dalam konteks auditing ini disebut dengan perilaku disfungsional. Perilaku ini pada gilirannya dapat memiliki pengaruh, baik langsung maupun tidak langsung terhadap kualitas audit (Donelly, Jeffrey, Quirin, \& Bryan, 2003). Perilaku yang mempunyai pengaruh langsung diantaranya adalah premature 
sign off atau penghentian prosedur audit secara dini, pemerolehan bukti yang kurang, pemrosesan yang kurang akurat, dan kesalahan dari tahapan-tahapan audit. Sementara perilaku yang mempunyai pengaruh tidak langsung terhadap kualitas audit adalah underreporting of time (Silaban, 2011). Perilaku tersebut dilakukan oleh auditor dalam rangka meraih target kinerja individual auditor. Berbagai penelitian menyatakan bahwa penyimpangan perilaku dalam penugasan telah menjadi permasalahan yang serius (Margheim, Kelly, \& Pattison, 2005).

Krisis kepercayaan akan profesi ini sangat terasa saat terjadinya kasus Enron pada tahun 2002 yang menjadi salah satu contoh keterpurukan nama akuntan publik. Dalam hal ini auditor melakukan perilaku yang merusak citra profesi akuntan publik. Auditor independen, Arthur Andersen bahkan ikut berperan dalam menyusun pembukuan kreatif Enron. Selain itu, jasa profesi akuntan publik di Indonesia juga pernah dinyatakan bersalah saat terjadinya kasus PT Great River International Tbk. Bapepam menyatakan bahwa akuntan publik yang memeriksa laporan keuangan Great River ikut menjadi tersangka. Maka dari itu Menteri Keuangan RI terhitung sejak tanggal 28 November 2006 telah membekukan izin akuntan publik Justinus Aditya Sidharta selama dua tahun karena terbukti melakukan pelanggaran terhadap Standar Profesi Akuntan Publik (SPAP) berkaitan dengan laporan Audit atas Laporan Keuangan Konsolidasi PT. Great River tahun 2003 (Pitaloka \& Widanaputra, 2016).

Pekerjaan audit harus dilakukan oleh auditor yang profesional. Dalam hal ini audit harus dilakukan oleh orang yang memiliki pengetahuan dan kemampuan teknis 
ISSN: 2302-8556

E-Jurnal Akuntansi Universitas Udayana

Vol.25.3.Desember (2018): 1826 - 1855

yang disyaratkan, serta etika demi menjamin kegiatan audit dilakukan secara efektif, efisien, ekonomis dan berkualitas. Namun, terkadang tekanan fee yang diterima oleh seorang auditor memaksa auditor untuk dapat mempersingkat jangka waktu dalam penyelesaian audit, sehingga auditor akan merasakan adanya time pressure dalam melaksanakan proses audit. Secara umum, banyak dari studi telah menunjukkan bahwa audit tekanan anggaran waktu telah meningkat dari waktu ke waktu (Bryan, Jeffrey, \& Donnelly, 2005).

Sebelum melakukan audit, Kantor Akuntan Publik perlu untuk mengestimasi waktu yang dibutuhkan (time budget). Penentuan kos audit dan efektivitas kinerja auditor dapat diukur pada saat penentuan anggaran waktu (Prasita \& Adi, 2007). Perilaku disfungsional akan lebih tinggi dalam kondisi time budget pressure yang tinggi (Gundry, 2007). Hal ini tentunya juga akan mempengaruhi kualitas audit. Banyak studi telah menunjukkan bahwa audit time budget pressure telah meningkat dari waktu ke waktu. Penelitian menunjukkan bahwa efektivitas audit dapat terpengaruh secara negatif sebagai akibat dari auditor terlibat dalam perilaku disfungsional (misalnya, premature sign-off dan underreporting of time) dalam rangka memenuhi anggaran waktu mereka (Margheim et al., 2005). Penelitian yang dilakukan oleh (Suprianto 2009) mengenai pengaruh time budget pressure terhadap perilaku disfungsional auditor (audit quality reduction behavior \& under reporting of time). Dalam penelitian ini ditunjukkan bahwa time budget pressure berpengaruh positif terhadap perilaku disfungsional auditor yaitu audit quality reduction 
behaviour dan under reporting of time.(Yuliana, Herawati, \& Arum, 2009) mengungkapkan time budget pressure dapat mendorong auditor untuk cenderung melakukan tindakan penurunan kualitas audit.

Locus of control juga dapat mempengaruhi dysfunctional audit behavior selain time budget pressure. Karakteristik personal auditor menjadi salah satu faktor penentu yang membedakan penerimaan auditor akan perilaku disfungsional. Locus of control merupakan salah satu aspek karakteristik kepribadian yang dimiliki oleh setiap individu dan dapat dibedakan atas locus of control internal dan locus of control eksternal.

Individu dengan internal locus of control memiliki kemampuan untuk menghadapi ancaman-ancaman yang timbul dari lingkungan dan berusaha memecahkan permasalahan dengan optimis, serta yakin dengan kemampuan mereka sendiri. Individu yang percaya bahwa peristiwa berada di bawah kendali mereka mengacu pada locus of control internal. (Samaei, Zahra, \& Semnani, 2012) menjelaskan bahwa individu dengan locus of control eksternal memiliki kontrol yang kurang terhadap kehidupan mereka dan percaya bahwa apa yang terjadi bagi mereka adalah hasil dari faktor eksternal. Individu dengan external locus of control lebih mudah terancam dan penyelesaian masalah cenderung reaktif (Febriana, 2012).

(Srimindarti, Sunarto, \& Listyorini, 2015) meneliti tentang pengaruh locus of control dan komitmen organisasi terhadap dysfunctional audit behavior, menunjukkan bahwa variabel locus of control internal berpengaruh negatif terhadap 
ISSN: 2302-8556

E-Jurnal Akuntansi Universitas Udayana

Vol.25.3.Desember (2018): 1826 - 1855

dysfunctional audit behavior. Auditor yang memiliki kecenderungan locus of control internal akan memiliki kinerja yang tinggi dan auditor yang memiliki kinerja yang tinggi tidak menerima dysfunctional audit behavior.

Selain time budget pressure dan locus of control, task complexity juga dapat mempengaruhi dysfunctional audit behavior. (Yuen, Chan, \& Guan, 2013) menyebutkan bahwa pekerjaan auditor adalah pekerjaan yang sangat menuntut, dengan adanya tekanan waktu yang harus dipenuhi. (Chung \& Monroe, 2001) mengemukakan bahwa audit task complexity dipengaruhi oleh dua faktor yaitu: banyaknya informasi yang tidak relevan dalam arti informasi tersebut tidak konsisten dengan kejadian yang akan diprediksikan, adanya ambiguitas yang tinggi yaitu beragamnya hasil yang diharapkan oleh klien dari dari kegiatan pengauditan. Pengujian pada variabel ini juga dirasa bersifat penting, karena kecenderungan bahwa tugas melakukan audit adalah tugas yang banyak menghadapi persoalan yang kompleks. Terdapat tiga alasan mendasar mengapa pengujian task complexity untuk sebuah situasi audit perlu dilakukan. Pertama, task complexity diduga berpengaruh signifikan terhadap kinerja seorang auditor. Kedua, sarana dan teknik pembuatan keputusan dan latihan tertentu diduga telah dikondisikan sedemikian rupa ketika para peneliti memahami keganjilan pada audit task complexity. Ketiga, pemahaman terhadap kompleksitas dari sebuah tugas dapat membantu tim manajemen audit perusahaan menemukan solusi terbaik bagi staf dan tugas audit (Widiarta, 2013). 
Penelitian yang dilakukan oleh (Dewi \& Wirasedana, 2015) menyimpulkan bahwa kompleksitas tugas berpengaruh positif terhadap perilaku disfungsional auditor.

Selain time budget pressure, locus of control, dan task complexity ada juga faktor lain yang dapat mempengaruhi dysfunctional audit behavior yaitu turnover intention. Turnover intention (keinginan untuk berhenti bekerja) didefinisikan sebagai kemauan dengan kesadaran dan perimbangan untuk meninggalkan organisasi (Maryanti, 2005). Memiliki keinginan untuk berhenti bekerja akan membuat seseorang menjadi kurang perduli terhadap apa yang dia lakukan diorganisasinya. Berhenti bekerja dapat mengakibatkan dan dapat mempengaruhi komitmen yang dimiliki karyawan terhadap organisasi. (Snead \& Harrel, 1991) menyatakan tingkat perilaku berpindah kerja para profesional di lingkungan KAP cukup tinggi. (Pujaningrum, Sabeni, \& Arifin, 2012) meneliti mengenai analisis faktor-faktor yang mempengaruhi tingkat penerimaan auditor atas penyimpangan perilaku dalam audit. Penelitian ini menemukan turnover intention berpengaruh positif pada dysfunctional audit behavior.

Peneliti tertarik untuk mengetahui bagaimana perilaku disfungsional audit pada Kantor Akuntan Publik yang terdaftar di Bali. Perilaku disfungsional auditor ini menarik untuk dikaji, karena auditor berperan penting dalam menyatakan kewajaran keadaan keuangan yang akan menjadi pedoman bagi pihak-pihak yang berkepentingan dengan perusahaan untuk mengambil keputusan tertentu.

Berdasarkan latar belakang diatas, penelitian ini dilakukan untuk mengembangkan penelitian yang dilakukan oleh (Dewi \& Wirasedana, 2015) dengan 
ISSN: 2302-8556

E-Jurnal Akuntansi Universitas Udayana

Vol.25.3.Desember (2018): 1826 - 1855

adanya penambahan variabel yaitu turnover intention. Peneliti mencoba mengkaji kembali penelitian dengan tujuan untuk menganalisis pengaruh time budget pressure, locus of control, task complexity, dan turnover intention pada dysfunctional audit behavior.

Adapun tujuan penelitian ini yaitu untuk mengetahui pengaruh time budget pressure pada dysfunctional audit behavior, untuk mengetahui pengaruh locus of control pada dysfunctional audit behavior, untuk mengetahui pengaruh task complexity pada dysfunctional audit behavior dan untuk mengetahui pengaruh turnover intention pada dysfunctional audit behavior.

Penelitian ini diharapkan dapat memberikan manfaat secara teoritis dan praktis antara lain penelitian ini diharapkan memberikan tambahan pengetahuan dan gambaran tentang faktor-faktor yang mempengaruhi dysfunctional audit behavior serta dapat mengetahui hubungan teoritis auditing yang diperoleh di bangku kuliah dalam kondisi sebenarnya di lapangan dan Penelitian ini diharapkan akan dapat memberikan kontribusi praktis, yaitu bagi Kantor Akuntan Publik memberikan gambaran nyata tentang dysfunctional audit behavior sehingga para auditor merencanakan prosedur dan penugasan audit dengan lebih matang pada audit berikutnya, serta sebagai acuan umpan balik yang bermanfaat dalam usaha evaluasi profesi akuntan publik demi peningkatan kualitas audit dan profesionalitasnya, serta untuk mendukung usaha pengedukasian masyarakat, khususnya pemakai laporan keuangan audit. 
Penelitian yang dilakukan oleh (Sososutiksno, 2010) dimana penelitian ini ditujukan untuk menguji pengaruh tekanan anggaran waktu terhadap perilaku disfungsional auditor antara lain premature sign-off, underreporting of time, dan audit quality reduction behavior. Hasil penelitian menunjukkan bahwa tekanan anggaran waktu berpengaruh positif terhadap perilaku disfungsional auditor yang dicirikan oleh tiga perilaku. Penelitian serupa yang dilakukan oleh (Suprianto, 2009) hasil penelitian menunjukkan bahwa tingkat tekanan anggaran waktu secara langsung berpengaruh positif terhadap perilaku disfungsional yaitu audit quality reduction behavior, premature sign-off, dan underreporting of time. Berdasarkan hal tersebut, maka hipotesis yang diajukan pada penelitian ini adalah.

$\mathrm{H}_{1}$ : Time budget pressure berpengaruh positif pada dysfunctional audit behavior.

(Gustati, 2012) meneliti tentang pengaruh locus of control yaitu locus of control internal dan locus of control eksternal terhadap penerimaan perilaku disfungsional audit dimana menunjukkan bahwa variabel locus of control internal berpengaruh negatif terhadap penerimaan perilaku disfungsional audit. Penelitian yang dilakukan oleh (Srimindarti et al., 2015) tentang pengaruh locus of control dan komitmen organisasi terhadap dysfunctional audit behavior, menunjukkan bahwa variabel locus of control internal berpengaruh negatif terhadap dysfunctional audit behavior. Berdasarkan hal tersebut, maka hipotesis yang diajukan pada penelitian ini adalah.

$\mathrm{H}_{2}$ : Locus of control internal berpengaruh negatif pada dysfunctional audit behavior. 
ISSN: 2302-8556

E-Jurnal Akuntansi Universitas Udayana

Vol.25.3.Desember (2018): 1826 - 1855

(Winanda \& Wirasedana, 2017) meneliti mengenai pengaruh tekanan anggaran waktu, sifat Machiavellian, dan kompleksitas tugas terhadap perilaku audit disfungsional. Hasil dari penelitian ini adalah bahwa kompleksitas tugas berpengaruh terhadap perilaku audit disfungsional. Penelitian yang dilakukan oleh (Dewi \& Wirasedana, 2015) menemukan bahwa task complexity berpengaruh positif pada dysfunctional audit behavior. Hal ini mengartikan bahwa semakin tinggi tingkat kesulitan sebuah tugas, maka semakin besar kecenderungan auditor untuk melakukan perilaku disfungsional. Berdasarkan uraian tersebut, maka hipotesis yang diajukan dalam penelitian ini adalah

$\mathrm{H}_{3}$ : Task Complexity berpengaruh positif pada dysfunctional audit behavior.

(Malone \& Roberts, 1998) menyatakan bahwa auditor yang memiliki keinginan berpindah kerja lebih mungkin terlibat dalam perilaku disfungsional karena adanya penurunan rasa takut dari kondisi yang mungkin terjadi bila perilaku tersebut terdeteksi. Jadi, auditor yang memiliki keinginan berpindah kerja lebih tinggi, diduga akan lebih menerima perilaku disfungsional. (Pujaningrum et al., 2012) meneliti mengenai analisis faktor-faktor yang mempengaruhi tingkat penerimaan auditor atas penyimpangan perilaku dalam audit. Penelitian ini menemukan turnover intention berpengaruh positif pada dysfunctional audit behavior. Penelitian yang dilakukan oleh (Fatimah, 2012) mengungkapkan bahwa keinginan untuk berhenti bekerja berpengaruh positif pada perilaku disfungsional auditor. Berdasarkan uraian tersebut, maka hipotesis yang diajukan dalam penelitian ini adalah 
$\mathrm{H}_{4}$ : Turnover intention berpengaruh positif pada dysfunctional audit behavior.

\section{METODE PENELITIAN}

Desain atau rancangan penelitian merupakan struktur atau strategi penelitian mengenai langkah awal hingga akhir mengenai tata cara yang dilakukan dalam penelitian ini membentuk proses dan hasil objektif, efektif, valid, dan efisiensi untuk menjawab pertanyaan yang ada. Penelitian ini menggunakan pendekatan kuantitatif berbentuk asosiatif. Penelitian asosiatif adalah penelitian yang bertujuan untuk mengetahui hubungan antara dua variabel atau lebih (Sugiyono, 2014). Berdasarkan hipotesis yang telah diuraikan sebelumnya, maka dapat dibuat hubungan antar variabel dependen dan independen sebagai berikut:

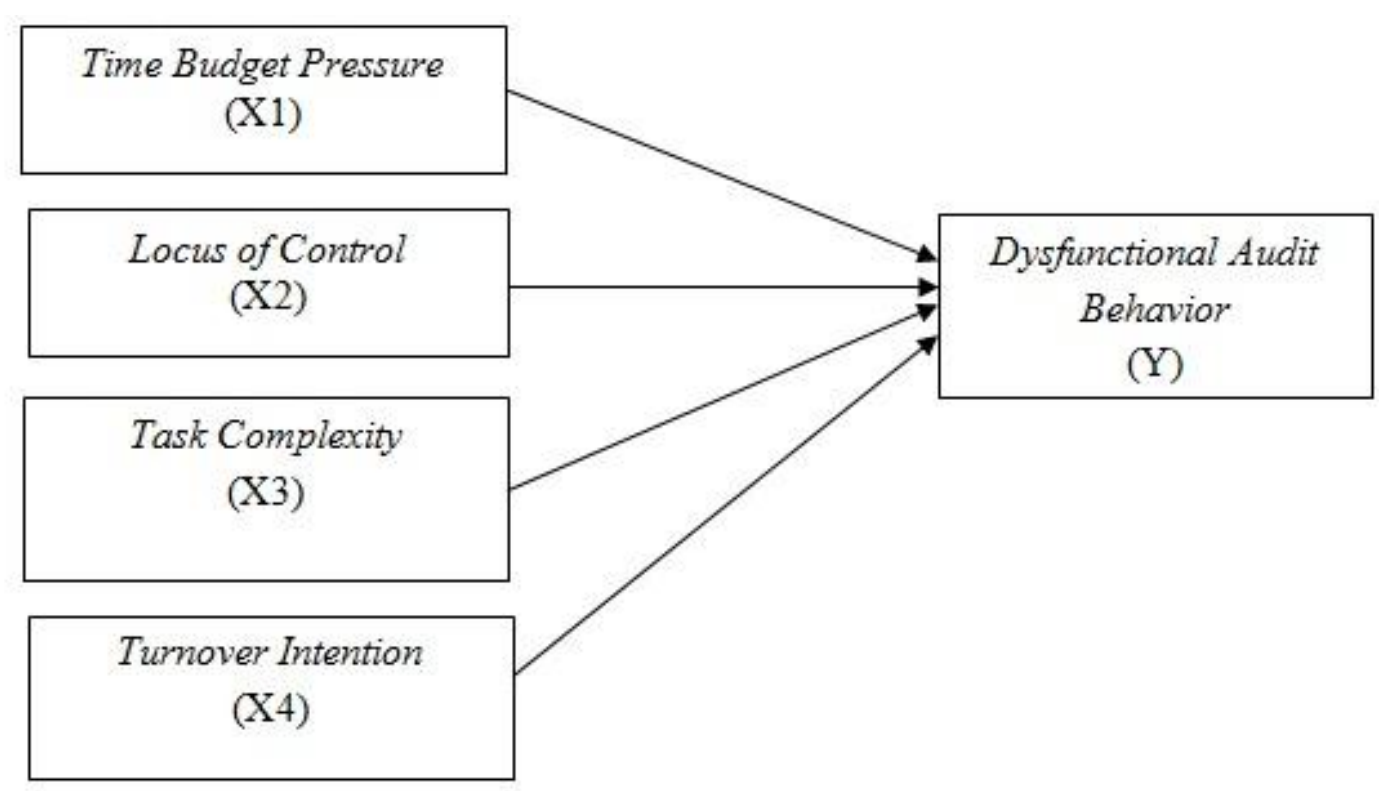

\section{Gambar 1. Kerangka Konseptual}

Penelitian ini dilakukan pada Kantor Akuntan Publik (KAP) yang berada di Bali yang terdaftar dalam Direktori yang diterbitkan oleh Institut Akuntan Publik 
ISSN: 2302-8556

E-Jurnal Akuntansi Universitas Udayana

Vol.25.3.Desember (2018): 1826 - 1855

Indonesia tahun 2017. Alasan dipilihnya lokasi ini karena kesempatan kerja yang tinggi sehingga tingkat turnover intention juga tinggi. Berikut pada Tabel 3.1. disajikan daftar dan alamat Kantor Akuntan Publik (KAP) di Bali.

Tabel 1.

Daftar Kantor Akuntan Publik di Bali

\begin{tabular}{|c|c|c|}
\hline No. & Nama Kantor Akuntan Publik & Alamat Kantor Akuntan Publik \\
\hline 1. & KAP I Wayan Ramantha & $\begin{array}{l}\text { Jl. Raya Batubulan, Banjar Tegal Tamu, } \\
\text { Batubulan, Sukawati, Kabupaten Gianyar, } \\
\text { Bali. Telp: (0361) } 80233\end{array}$ \\
\hline 2. & $\begin{array}{l}\text { KAP Johan Malonda Mustika \& Rekan } \\
(\mathrm{Cab})\end{array}$ & $\begin{array}{l}\text { J1. Muding Indah 1/5, Kerobokan, Kuta } \\
\text { Utara, Badung, Bali. Telp: (0361) } 434884\end{array}$ \\
\hline 3. & KAP K. Gunarsa & $\begin{array}{l}\text { J1. Tukad Banyusari Gg. II No 5. Telp: } \\
\text { (0361) } 225580\end{array}$ \\
\hline 4. & KAP Drs. Ketut Budiartha, M.Si & $\begin{array}{l}\text { Perum Padang Pesona Graha Adhi,Blok A6, } \\
\text { Jl. Gunung Agung Denpasar, Bali. Telp: } \\
\text { (0361) } 8849168\end{array}$ \\
\hline 5. & $\begin{array}{l}\text { KAP Drs. Sri Marno Djogokarsono \& } \\
\text { Rekan }\end{array}$ & $\begin{array}{l}\text { Jl. Gunug Muria Blok VE No.4, Monang } \\
\text { Maning, Denpasar, Bali. Telp: (0361) } \\
\text { 480033, 480032, 482422 }\end{array}$ \\
\hline 6. & KAP Drs. Wayan Sunasdyana & $\begin{array}{l}\text { J1. Pura Demak I Gang Buntu No. } 89 \text {, } \\
\text { Denpasar, Bali. Telp: (0361) 7223329, } \\
8518989\end{array}$ \\
\hline 7. & KAP Drs. Ketut Muliartha R.M \& Rekan & J1. Drupadi No. 25 Denpasar, Bali \\
\hline 8. & KAP Aryana dan Darmayasa & $\begin{array}{l}\text { Jl. Cargo Indah III A Perum Melang Hill } \\
\text { No. } 1 \text { Ubung, Denpasar Utara. Telp: (0361) } \\
4714308\end{array}$ \\
\hline 9. & KAP Budhananda Munidewi & $\begin{array}{l}\text { J1. Tukad Irawadi No. 18A, Lantai 2, } \\
\text { Kelurahan Panjer, Denpasar Selatan. Telp: } \\
\text { (0361) } 265644\end{array}$ \\
\hline
\end{tabular}

Sumber: Directory IAPI, 2017

Obyek penelitian ini adalah pengaruh dysfunctional audit behavior Kantor

Akuntan Publik yang berlokasi di Provinsi Bali yang terdaftar sebagai anggota Institut Akuntan Publik Indonesia (IAPI) tahun 2017.Variabel independen (variabel bebas) dalam penelitian ini adalah time budget pressure, locus of control, task complexity, turnover intention.

Populasi dalam penelitian ini adalah seluruh auditor yang bekerja pada Kantor Akuntan Publik (KAP) di Bali. Peneliti memilih auditor sebagai populasi karena 
auditor langsung terjun ke lapangan dalam melakukan profesi auditnya sehingga lebih rentan terhadap penerimaan dysfunctional audit behavior dalam melakukan proses audit yang dapat mempengaruhi hasil audit. Rincian auditor yang bekerja di KAP Provinsi Bali disajikan dalam Tabel 2 berikut:

\section{Tabel 2.}

Jumlah Auditor Pada Kantor Akuntan Publik di Bali

\begin{tabular}{clc}
\hline No. & \multicolumn{1}{c}{ Nama Kantor Akuntan Publik } & Jumlah Auditor (orang) \\
\hline 1. & KAP I Wayan Ramantha & 12 \\
2. & KAP Johan Malonda Mustika \& Rekan (Cab) & 10 \\
3. & KAP K. Gunarsa & 8 \\
4. & KAP Drs. Ketut Budiartha, M.Si & 6 \\
5. & KAP Drs. Sri Marmo Djogokarsono \& Rekan & 16 \\
6. & KAP Drs. Wayan Sunasdyana & 6 \\
7. & KAP Drs. Ketut Muliartha R.M \& Rekan & 11 \\
8. & KAP Aryana dan Darmayasa & 2 \\
9. & KAP Budhananda Munidewi & 7 \\
Total & & 78 \\
\hline
\end{tabular}

Sumber: Data diolah, 2017

Terdapat dua cara pengambilan sampel penelitian yakni Probability Sampling dan Non Probability Sampling. Metode pengumpulan sampel yang digunakan dalam penelitian ini adalah non probability sampling dengan teknik purposive sampling, yaitu metode penentuan sampel dengan pertimbangan tertentu dimana anggota sampel akan dipilih sedemikian rupa sehingga sampel tersebut dapat mewakili sifat - sifat populasi (Sugiyono, 2014). Berdasarkan metode tersebut, maka yang menjadi sampel dalam penelitian ini adalah seluruh populasi yaitu 78 auditor yang menjadi anggota IAPI yang bekerja di masing - masing KAP di Provinsi Bali tidak dibatasi oleh jabatan auditor tersebut baik sebagai manajer, senior auditor, junior auditor, dan partner. 
ISSN: 2302-8556

E-Jurnal Akuntansi Universitas Udayana

Vol.25.3.Desember (2018): 1826 - 1855

Kriteria yang dijadikan dasar pemilihan anggota sampel adalah auditor yang sudah pernah melakukan atau menyelesaikan tugas pemeriksaan sebelumnya. Kriteria ini digunakan karena auditor yang sudah pernah melakukan audit telah memiliki kemampuan dan pengetahuan, sehingga mampu memberikan jawaban maupun pernyataan yang tertera pada kuesioner dengan baik dan auditor yang memiliki pengalaman kerja minimal 1 tahun. Kriteria ini digunakan karena auditor yang memiliki pengalaman minimal 1 tahun memiliki waktu dan pengalaman untuk beradaptasi serta menilai kondisi lingkungan kerjanya.

Dalam penelitian ini pengumpulan data yang dilakukan oleh peneliti menggunakan metode survei. Kuesioner yang disebarkan berupa serangkaian pertanyaan dan pernyataan tertulis mengenai pengaruh time budget pressure, locus of control, dan task complexity pada dysfunctional audit behavior Kantor Akuntan Publik di Bali. Metode ini digunakan untuk memperoleh data primer. Dalam penelitian ini kusioner akan diantarkan langsung ke lokasi penelitian, yaitu KAP yang termasuk di dalam Institut Akuntan Publik Indonesia (IAPI) tahun 2017. Kuesioner yang telah diisi dikembalikan secara langsung kepada peneliti. Hasil jawaban kemudian diukur dengan menggunakan skala likert, yaitu pilihan jawaban responden diberi nilai dengan skala 5 poin, skor tertinggi adalah 5 dan skor terendah adalah 1.

Berdasarkan jenisnya data dapat dibedakan menjadi dua yaitu sebagai berikut Penelitian ini menggunakan data kuantitatif yang berupa jumlah auditor yang bekerja di masing - masing KAP, serta hasil kuesioner diukur menggunakan skala likert dan 
Data kualitatif juga merupakan data yang dinyatakan dalam bentuk kata, kalimat, dan skema. Data kualitatif dalam penelitian ini berupa daftar nama KAP di Provinsi Bali tahun 2017.

Data primer dalam penelitian ini adalah jawaban responden melalui kuesioner dan data sekunder dalam penelitian ini adalah data yang dikumpulkan dari sumber lain yaitu daftar Kantor Akuntan Publik (KAP) yang terdaftar pada IAPI di Provinsi Bali

Pada penelitian ini digunakan teknik analisis regresi linear berganda yang diuji dengan tingkat signifikansi 0,05. Analisis regresi linear berganda digunakan untuk mengetahui atau memperoleh gambaran mengenai pengaruh variabel bebas $\left(\mathrm{X}_{1}, \mathrm{X}_{2}, \mathrm{X}_{3}, \mathrm{X}_{4}\right)$ pada variabel terikat $(\mathrm{Y})$. Analisis ini dilakukan dengan menggunakan bantuan program komputer Statistical Package for Social Science (SPSS). Model regresi linear berganda di tunjukkan oleh persamaan sebagai berikut.

$\hat{Y}=\alpha+\beta_{1} X_{1}+\beta_{2} X_{2}+\beta_{3} X_{3}+\beta_{4} X_{4}+e$

$$
\begin{array}{ll}
\text { Keterangan } \\
\hat{\mathrm{Y}} & =\text { Dysfunctional Audit Behavior } \\
\alpha & =\text { konstanta } \\
\beta & =\text { koefisien regresi parsial } \\
\mathrm{X}_{1} & =\text { Time Budget Pressure } \\
\mathrm{X}_{2} & =\text { Locus of Control } \\
\mathrm{X}_{3} & =\text { Task Complexity } \\
\mathrm{X}_{4} & =\text { Turnover Intention } \\
\mathrm{e} & =\text { standar error }
\end{array}
$$


ISSN: 2302-8556

\section{HASIL DAN PEMBAHASAN}

Uji validitas dilakukan dengan menghitung nilai pearson correlation. Instrumen dapat dikatakan valid jika nilai $\mathrm{r}$ pearson correlation $\geq \mathrm{r}_{\mathrm{kritis}}(0,30)$ (Sugiyono, 2014). Tabel 3 menyajikan hasil uji validitas instrumen penelitian.

Tabel 3. Hasil Uji Validitas

\begin{tabular}{clcc}
\hline No & \multicolumn{1}{c}{ Variabel } & Pearson Correlation & Keterangan \\
\hline 1 & Dysfunctional Audit Behavior $(\mathrm{Y})$ & $0,810-0,948$ & Valid \\
2 & Time Budget Pressure $\left(\mathrm{X}_{1}\right)$ & $0,849-0,944$ & Valid \\
3 & Locus of Control $\left(\mathrm{X}_{2}\right)$ & $0,803-0,901$ & Valid \\
4 & Task Complexity $\left(\mathrm{X}_{3}\right)$ & $0,818-0,924$ & Valid \\
5 & Turnover Intention $\left(\mathrm{X}_{4}\right)$ & $0,860-0,920$ & Valid \\
\hline
\end{tabular}

Sumber: Data diolah, 2018

Berdasarkan Tabel 3 diketahui bahwa setiap indikator pernyataan dalam variabel time budget pressure, locus of control, task complexity,turnover intention dan dysfunctional audit behavior memenuhi syarat validitas karena nilai korelasi antara skor butir dengan skor total menunjukkan hasil yang signifikan, bernilai positif dan nilainya lebih dari 0,30 . Sehingga dapat disimpulkan bahwa seluruh indikator telah memenuhi persyaratan uji validitas.

Pengujian reliabilitas ini menggunakan uji statistik Cronbach Alpha. Instrumen dikatakan reliabel jika nilai Cronbach Alpha lebih besar dari 0,70 (Ghonzali, 2016). Hasil uji reliabilitas dapat dilihat pada Tabel 4. 
Tabel 4.

Hasil Uji Reliabilitas

\begin{tabular}{lcc}
\hline \multicolumn{1}{c}{ Variabel } & Cronbach's Alpha & Keterangan \\
\hline Dysfunctional Audit Behavior $(\mathrm{Y})$ & 0,971 & Reliabel \\
Time Budget Pressure $\left(\mathrm{X}_{1}\right)$ & 0,955 & Reliabel \\
Locus of Control $\left(\mathrm{X}_{2}\right)$ & 0,964 & Reliabel \\
Task Complexity $\left(\mathrm{X}_{3}\right)$ & 0,940 & Reliabel \\
Turnover Intention $\left(\mathrm{X}_{4}\right)$ & 0,909 & Reliabel \\
\hline
\end{tabular}

Sumber: Data diolah, 2018

Berdasarkan Tabel 4 menunjukkan bahwa nilai Cronbach Alpha masingmasing variabel memiliki nilai lebih besar dari 0,70. Jadi dapat disimpulkan bahwa pernyataan dalam kuesioner penelitian ini reliabel dandapat digunakan.

Tabel 5.

Hasil Uji Normalitas

\begin{tabular}{llll}
\hline No. & Persamaan & Z & Asymp. Sig. \\
\hline 1. & $\mathrm{Y}=\alpha+\beta_{1} \mathrm{X}_{1+} \beta_{2} \mathrm{X}_{2+} \beta_{3} \mathrm{X}_{3+} \beta_{4} \mathrm{X}_{4+} \varepsilon$ & 0,109 & 0,200 \\
\hline Sumber $:$ Data diolah, 2018 & &
\end{tabular}

Berdasarkan Tabel 5 dapat dilihat bahwa nilai dari asymp. Sig (2-tailed)= 0,200 lebih besar daripada nilai level of significant $=0,05$, Hal ini menunjukkan bahwa model persamaan regresi memenuhi uji normalitas karena nilai Asymp. Sig. lebih besar dari 0,05. Dapat disimulkan data dalam penelitian ini berdistribusi normal.

Model regresi yang bebas dari multikolinearitas, jika nilai tolerance $>10 \%$ atau VIF <10 (Ghonzali, 2016). Hasil uji multikolinearitas dapat dilihat pada Tabel 6 Berdasarkan Tabel 6 dapat disimpulkan bahwa nilai tolerance pada masing-masing variabel bernilai diatas $10 \%(0,10)$ dan nilai VIF dibawah 10 . Hal ini menjelaskan bahwa regresi kedua model yang ada tidak terjadi multikolinearitas. 
ISSN: 2302-8556

E-Jurnal Akuntansi Universitas Udayana

Vol.25.3.Desember (2018): 1826 - 1855

Tabel 6.

Hasil Uji Multikolinearitas

\begin{tabular}{lcc}
\hline \multicolumn{1}{c}{ Variabel } & Tolerance & VIF \\
\hline Time Budget Pressure $\left(\mathrm{X}_{1}\right)$ & 0,828 & 1,207 \\
Locus of Control $\left(\mathrm{X}_{2}\right)$ & 0,695 & 1,439 \\
Task Complexity $\left(\mathrm{X}_{3}\right)$ & 0,727 & 1,375 \\
Turnover Intention $\left(\mathrm{X}_{4}\right)$ & 0,718 & 1,393 \\
\hline
\end{tabular}

Sumber: Data diolah, 2018

Uji heterokedastisitas dilakukan untuk menguji model regresi apakah terjadi ketidaksamaan varian dari residual satu pengamatan ke pengamatan lainnya. Hasil uji glejser dapat dilihat pada Tabel 7.

Tabel 7.

Hasil Uji Heteroskedastisitas

\begin{tabular}{lcl}
\hline \multicolumn{1}{c}{ Variabel } & Sig. & \multicolumn{1}{c}{ Keterangan } \\
\hline Time Budget Pressure $\left(\mathrm{X}_{1}\right)$ & 0,130 & Bebas heteroskedastisitas. \\
Locus of Control $\left(\mathrm{X}_{2}\right)$ & 0,279 & Bebas heteroskedastisitas. \\
Task Complexity $\left(\mathrm{X}_{3}\right)$ & 0,613 & Bebas heteroskedastisitas. \\
Turnover Intention $\left(\mathrm{X}_{4}\right)$ & 0,992 & Bebas heteroskedastisitas. \\
\hline
\end{tabular}

Sumber: Data diolah, 2018

Berdasarkan Tabel 7 dapat disimpulkan bahwa nilai signifikansi masingmasing variabel pada model regresi ini nilainya melebihi 0,05 . Hal ini menunjukkan bahwa model regresi tersebut bebas dari gejala heterokedastisitas.

Hasil statistik deskriptif dapat dilihat pada Tabel 4.6

Tabel 8.

Hasil Statistik Deskriptif

\begin{tabular}{lccccc}
\hline \multicolumn{1}{c}{ Variabel } & N & Min. & Max. & Mean & Std. Deviasi \\
\hline Dysfunctional Audit Behavior & 42 & 13,00 & 49,48 & 25,71 & 10,38 \\
Time Budget Pressure & 42 & 7,00 & 27,40 & 14,34 & 6,33 \\
Locus of Control & 42 & 12,04 & 44,08 & 32,26 & 9,53 \\
Task Complexity & 42 & 6,00 & 23,88 & 12,55 & 5,32 \\
Turnover Intention & 42 & 4,00 & 16,98 & 9,53 & 3,64 \\
\hline
\end{tabular}

Sumber: Data diolah, 2018 
Berdasarkan Tabel 8 dapat dilihat bahwa variabel dysfunctional audit behavior (Y) memiliki nilai minimum sebesar 13,00, nilai maksimum sebesar 49,48, mean sebesar 25,71, dan standar deviasi sebesar 10,38. Ini berarti bahwa terjadi perbedaan nilai dysfunctional audit behavior yang diteliti terhadap nilai rata-ratanya sebesar 10,38 .

Variabel time budget pressure $\left(\mathrm{X}_{1}\right)$ memiliki nilai minimum sebesar 7,00 , nilai maksimum sebesar 27,40, mean sebesar 14,34, dan standar deviasi sebesar 6,33 . Ini berarti bahwa terjadi perbedaan nilai time budget pressure yang diteliti terhadap nilai rata-ratanya sebesar 6,33 . Variabel locus of control $\left(\mathrm{X}_{2}\right)$ memiliki nilai minimum sebesar 12,04, nilai maksimum sebesar 44,08, mean sebesar 32,26, dan standar deviasi sebesar 9,53. Ini berarti bahwa terjadi perbedaan nilai locus of control yang diteliti terhadap nilai rata-ratanya sebesar 9,53.

Variabel task complexity $\left(\mathrm{X}_{3}\right)$ memiliki nilai minimum sebesar 6,00, nilai maksimum sebesar 23,88, mean sebesar 12,55, dan standar deviasi sebesar 5,32. Ini berarti bahwa terjadi perbedaan nilai task complexity yang diteliti terhadap nilai rataratanya sebesar 5,32. Variabel turnover intention $\left(\mathrm{X}_{4}\right)$ memiliki nilai minimum sebesar 4,00, nilai maksimum sebesar 16,98, mean sebesar 9,53, dan standar deviasi sebesar 3,64. Ini berarti bahwa terjadi perbedaan nilai turnover intention yang diteliti terhadap nilai rata-ratanya sebesar 3,64. 
ISSN: 2302-8556

E-Jurnal Akuntansi Universitas Udayana

Vol.25.3.Desember (2018): 1826 - 1855

Analisis regresi linier berganda digunakan untuk memecahkan rumusan masalah yang ada, yaitu untuk melihat pengaruh antara dua variabel atau lebih. Hasil analisis regresi linier berganda dapat dilihat pada Tabel 9.

Tabel 9.

Hasil Analisis Regresi Linear Berganda

\begin{tabular}{lccccc}
\hline \multicolumn{1}{c}{ Variabel } & \multicolumn{2}{c}{$\begin{array}{c}\text { Unstandardized } \\
\text { Coefficients }\end{array}$} & $\begin{array}{c}\text { Standardized } \\
\text { Coefficients } \\
\text { Beta }\end{array}$ & t & Sig. \\
& B & Std. Error & & & \\
\hline (Constant) & 11,308 & 5,665 & & 1,996 & 0,053 \\
Time Budget Pressure & 0,624 & 0,140 & 0,381 & 4,461 & 0,000 \\
$\left(\mathrm{X}_{1}\right)$ & & & $-0,256$ & $-2,748$ & 0,009 \\
Locus of Control $\left(\mathrm{X}_{2}\right)$ & $-0,279$ & 0,102 & 0,344 & 3,776 & 0,001 \\
Task Complexity $\left(\mathrm{X}_{3}\right)$ & 0,671 & 0,178 & 0,222 & 2,421 & 0,020 \\
Turnover Intention $\left(\mathrm{X}_{4}\right)$ & 0,633 & 0,261 & & & \\
Adjusted $\mathbf{R}^{\mathbf{2}}$ & 0,752 & & & & \\
F Hitung & 32,124 & & & & \\
Sig. F & 0,000 & & & &
\end{tabular}

Berdasarkan Tabel 9 dapat disusun persamaan regresi sebagai berikut.

$$
Y=11,308+0,624 X_{1}-0,279 X_{2}+0,671 X_{3}+0,633 X_{4}+\varepsilon
$$

Berdasarkan persamaan di atas, dapat dijelaskan bahwa nilai konstanta sebesar 11,308 menunjukan bahwa bila nilai time budget pressure $\left(\mathrm{X}_{1}\right)$, locus of control $\left(\mathrm{X}_{2}\right)$,task complexity $\left(\mathrm{X}_{3}\right)$, dan turnover intention $\left(\mathrm{X}_{4}\right)$ sama dengan nol, maka nilai dysfunctional audit behaviormeningkat sebesar 11,308.

Nilai koefisien $\beta_{1}=0,624$ bertanda positif ini berarti bila terjadi peningkatan time budget pressure $\left(\mathrm{X}_{1}\right)$, maka dysfunctional audit behavior $(\mathrm{Y})$ akan cenderung mengalami peningkatan. Nilai koefisien $\beta_{2}=-0,279$ bertanda negatif ini berarti bila 
terjadi peningkatan locus of control $\left(\mathrm{X}_{2}\right)$, maka dysfunctional audit behavior (Y) akan cenderung mengalami penurunan.

Nilai koefisien $\beta_{3}=0,671$ bertanda positif ini berarti bila terjadi peningkatan task complexity $\left(\mathrm{X}_{3}\right)$, maka dysfunctional audit behavior $(\mathrm{Y})$ akan cenderung mengalami peningkatan. Nilai koefisien $\beta_{4}=0,633$ bertanda positif ini berarti bila terjadi peningkatan turnover intention $\left(\mathrm{X}_{4}\right)$, maka dysfunctional audit behavior (Y) akan cenderung mengalami peningkatan.

Berdasarkan tabel 9 hasil uji $\mathrm{F}$ (Ftest) menunjukkan bahwa nilai $\mathrm{F}$ hitung sebesar 32,124 dengan signifikan $\mathrm{F}$ atau $\mathrm{P}$ value 0,000 yang lebih kecil dari $\alpha=0,05$, ini berarti model yang digunakan pada penelitian ini adalah layak digunakan. Hasil ini memberikan makna bahwa keempat variabel independen yaitu time budget pressure $\left(\mathrm{X}_{1}\right)$, locus of control $\left(\mathrm{X}_{2}\right)$, task complexity $\left(\mathrm{X}_{3}\right)$, dan turnover intention $\left(\mathrm{X}_{3}\right)$ mampu memprediksi atau menjelaskan fenomena dysfunctional audit behavior.

Pada tabel 9 dapat dilihat bahwa model summary besarnya Adjusted $\mathrm{R}^{2}$ adalah 0,752. Ini berarti variasi dysfunctional audit behavior dapat dijelaskan oleh variasi time budget pressure, locus of control, task complexity, dan turnover intentionsebesar 75,2 persen, sedangkan sisanya sebesar 24,8 persen dijelaskan oleh faktor-faktor lain.

Berdasarkan Tabel 9 dapat diketahui bahwa nilai sig tesdari $\mathrm{X}_{1}$ (time budget pressure) adalah sebesar 0,000. Nilai ini lebih kecil dari $\alpha=0,05$ yang berarti hipotesis pertama $\left(\mathrm{H}_{1}\right)$ diterima. Untuk itu berdasarkan hasil pengujian hipotesis 
ISSN: 2302-8556

E-Jurnal Akuntansi Universitas Udayana

Vol.25.3.Desember (2018): 1826 - 1855

maka time budget pressure auditor berpengaruh positif dan signifikan pada dysfunctional audit behavior.

Berdasarkan tabel 9 dapat diketahui bahwa nilai sig tes dari $\mathrm{X}_{2}$ (locus of control) adalah sebesar 0,009 . Nilai ini lebih kecil dari $\alpha=0,05$ yang berarti hipotesis kedua $\left(\mathrm{H}_{2}\right)$ diterima. Untuk itu berdasarkan hasil pengujian hipotesis maka locus of control auditor berpengaruh negatif dan signifikan pada dysfunctional audit behavior.

Berdasarkan tabel 9 dapat diketahui bahwa nilai sig tes dari $\mathrm{X}_{3}$ (task complexity) adalah sebesar 0,001 . Nilai ini lebih kecil dari $\alpha=0,05$ yang berarti hipotesis ketiga $\left(\mathrm{H}_{3}\right)$ diterima. Untuk itu berdasarkan hasil pengujian hipotesis maka task complexity auditor berpengaruh positif dan signifikan pada dysfunctional audit behavior.

Berdasarkan tabel 9 dapat diketahui bahwa nilai sig tes dari $\mathrm{X}_{4}$ (turnover intention) adalah sebesar 0,020. Nilai ini lebih kecil dari $\alpha=0,05$ yang berarti hipotesis keempat $\left(\mathrm{H}_{4}\right)$ diterima. Untuk itu berdasarkan hasil pengujian hipotesis maka turnover intention auditor berpengaruh positif dan signifikan pada dysfunctional audit behavior.

Hasil perhitungan yang ditunjukan pada Tabel 8 diketahui bahwa nilai $\beta_{1}=$ 0,624 dengan tingkat signifikansi t sebesar 0,000 yang berarti dibawah nilai $\alpha=0,05$. Hipotesis pertama $\left(\mathrm{H}_{1}\right)$ yang menyatakan time budget pressure berpengaruh positif pada dysfunctional audit behavior diterima. Ini berarti penelitian ini menunjukan bahwa semakin tinggi tingkat time budget pressure maka tingkat penerimaan auditor 
terhadap dysfunctional audit behavior juga semakin tinggi, dimana kecenderungan auditor akan melakukan dysfunctional audit behavior dalam mengaudit laporan keuangan akan semakin tinggi. Sebaliknya apabila semakin rendah time budget pressure maka semakin rendah dysfunctional audit behavior.

Hasil perhitungan yang ditunjukan pada Tabel 8 diketahui bahwa nilai $\beta_{2}=-$ 0,279 dengan tingkat signifikansi t sebesar 0,009 yang berarti dibawah nilai $\alpha=0,05$. Hipotesis kedua $\left(\mathrm{H}_{2}\right)$ yang menyatakan locus of control internal berpengaruh negatif pada dysfunctional audit behavior diterima.Skor yang lebih rendah nilainya dari nilai median skor locus of control berhubungan dengan perilaku atau sikap internal. Ini berarti bahwa auditor yang memiliki kecenderungan locus of control internal tidak mudah menerima perilaku disfungsional audit atau dysfunctional audit behavior.

Hasil perhitungan yang ditunjukan pada Tabel 8 diketahui bahwa nilai $\beta_{3}=$ 0,71 dengan tingkat signifikansi t sebesar 0,001 yang berarti dibawah nilai $\alpha=0,05$. Hipotesis ketiga $\left(\mathrm{H}_{3}\right)$ yang menyatakan task complexity berpengaruh positif pada dysfunctional audit behavior diterima. Ini berarti penelitian ini menunjukan bahwa semakin tinggi tingkat task complexity maka tingkat penerimaan auditor terhadap dysfunctional audit behavior juga semakin tinggi. Sebaliknya apabila semakin rendah task complexity maka semakin rendah dysfunctional audit behavior.

Hasil perhitungan yang ditunjukan pada Tabel 9 diketahui bahwa nilai $\beta_{4}=$ 0,633 dengan tingkat signifikansi t sebesar 0,020 yang berarti dibawah nilai $\alpha=0,05$. Hipotesis keempat $\left(\mathrm{H}_{4}\right)$ yang menyatakan turnover intention berpengaruh positif pada 
ISSN: 2302-8556

E-Jurnal Akuntansi Universitas Udayana

Vol.25.3.Desember (2018): 1826 - 1855

dysfunctional audit behavior diterima. Ini berarti penelitian ini menunjukan bahwa semakin tinggi tingkat turnover intention maka tingkat penerimaan auditor terhadap dysfunctional audit behavior juga semakin tinggi. Sebaliknya apabila semakin rendah turnover intention maka semakin rendah dysfunctional audit behavior.

\section{SIMPULAN}

Penelitian ini bertujuan untuk mengetahui pengaruh time budget pressure, locus of control, task complexity, dan turnover intention pada dysfunctional audit behavior Kantor Akuntan Publik di Bali. Berdasarkan hasil analisis dan pembahasan yang telah dilakukan pada bab sebelumnya, maka dapat ditarik kesimpulan sebagai berikut. Time budget pressure berpengaruh posistif pada dysfunctional audit behavior Kantor Akuntan Publik di Bali.Kondisi ini menggambarkan bahwa semakin tinggi tingkat time budget pressure yang diterima oleh seorang auditor maka tingkat penerimaan auditor terhadap dysfunctional audit behavior juga akan semakin tinggi. Locus of control internal berpengaruh negatif pada dysfunctional audit behavior Kantor Akuntan Publik di Bali. Kondisi ini menggambarkan bahwa semakin tinggi tingkat locus of control seorang auditor maka tingkat penerimaan auditor terhadap dysfunctional audit behavior juga akan semakin rendah. Hal ini dikarenakan auditor dengan locus of control internal memiliki kemampuan untuk menghadapi ancamanancaman yang timbul dari lingkungan dan berusaha untuk memecahkan masalah dengan optimis dan yakin akan kemampuan mereka sendiri. 
Task complexity berpengaruh positif pada dysfunctional audit behavior Kantor Akuntan Publik di Bali. Kondisi ini menggambarkan bahwa semakin tinggi tingkat task complexity yang diterima oleh seorang auditor maka tingkat penerimaan auditor terhadap dysfunctional audit behavior juga akan semakin tinggi. Turnover intention berpengaruh positif pada dysfunctional audit behavior kantor akuntan publik di Bali. Kondisi ini menggambarkan bahwa semakin tinggi tingkat turnover intention seorang auditor maka tingkat penerimaan auditor terhadap dysfunctional audit behavior juga akan semakin tinggi.

Berdasarkan keterbatasan dan kelemahan yang ada dalam penelitian ini, maka dapat dikemukakan beberapa saran yang dapat dijadikan pertimbangan untuk peneliti yang ingin melakukan penelitian lanjutan, yaitu bagi kantor akuntan publik, time budget sebaiknya direncanakan dan diperhitungkan dengan lebih matang karena jika time budget semakin singkat dan sulit untuk dicapai maka akan membawa tingkat tekanan yang besar bagi auditor sehingga auditor akan cenderung melakukan segala perilaku yang dianggapnya dapat menyelesaikan tugasnya tepat pada waktunya sedangkan peneliti selanjutnya disarankan untuk memperluas wilayah penelitian hingga keluar Bali atau mungkin bisa dikembangkan pada kantor akuntan publik di seluruh Indonesia sehingga hasil penelitian dapat digeneralisasikan. Hal ini dikarenakan hasil penelitian mungkin saja berbeda jika diterapkan padawilayah penelitian kantor akuntan publik di luar Bali bahkan seluruh Indonesia, sehingga hasil penelitian nantinya dapat dibandingkan dengan penelitian-penelitian sebelumnya. 
ISSN: 2302-8556

E-Jurnal Akuntansi Universitas Udayana

Vol.25.3.Desember (2018): 1826 - 1855

Serta peneliti selanjutnya dapat menambah variabel lain yang diduga berpengaruh terhadap dysfunctional audit behavior.

\section{REFERENSI}

Arens, \& Loebbeck. (2003). Auditing Pendekatan Terpadu (Indonesia). Jakarta: Salemba Empat.

Bryan, D., Jeffrey, \& Donnelly. (2005). Locus of Control and Dysfunctional Audit Behavior. Journal of Business and Economics Research, 3(10), 9-14.

Chanawongse, Kasom, Poonpol, Parnsiri, \& Nuttavong. (2011). The Effect of Auditor Professional on Audit Quality: An Empirical Study of Certified Public Accountants (CPAs) in Thailand. International Academy Bisnis \& Ekonomi.

Chiang, H.-T., \& Lin, S.-L. (2012). Effect Of Auditor's Judgment And Specialization On Thir Differential Opinion Between Semiannual And Annual Financial Reports. Global Journal of Business Research, 6 (4), 1-22.

Chung, J., \& Monroe, G. (2001). A Research Note on The Effect of Gender and Task Complexity on an Audit Judgment. Journal of Behavioral Research in Accounting, 13(1), 111-125.

Dewi, N. R., \& Wirasedana. (2015). Pengaruh Time Budget Pressure, Locus of Control, Task Complexity pada Dysfunctional Audit Behavior. E-Jurnal Akuntansi Universitas Udayana, 11(1), 1-14.

Donelly, D., Jeffrey, Quirin, \& Bryan, D. O. (2003). Attitudes Toward Dysfunctional Audit Behavior: The Effects of Locus of Control, Organizational Commitment, and Position. The Journal of Applied Business Research, 19(1).

Fatimah, A. (2012). Karakteristik Personal Auditor sebagai Anteseden Perilaku Disfungsional Auditor dan Pengaruhnya terhadap Kualitas Hasil Audit. Jurnal Manajemen Dan Akuntansi, 1(1), 1-12.

Febriana, H. L. (2012). Analisis Pengaruh Karaktristik Personal Auditor terhadap Penerimaan Auditor atas Dysfungsional Audit Behavior (Studi Empiris pada Kantor Akuntan Publik di Jawa Tengah dan DI Yogyakarta). Universitas Diponegoro, Semarang. 
Gabrini, C. J. (2013). The Effect Of Internal Audit On Governmance: Maintaining Legitimacy Of Local Government. Jurnal The Florida State DigiNole Commons, 7(9), 1-121.

Ghonzali, I. (2016). Aplikasi Analisis Multivariate Dengan Program IBM SPSS 23 (8th ed.). Semarang: Badan Penerbit Universitas Diponogoro.

Gundry, L. C. (2007). Time Budget Pressure and Auditors Personality Type on Reduced Audit Quality Practices. Pacific Accounting Review, 19(2), 125-152.

Gustati. (2012). Persepsi Auditor Tentang Pengaruh Locus of Control Terhadap Penerimaan Perilaku Disfungsional Audit (Survey Pada Auditor BPKP Perwakilan Provinsi Sumatera Barat). Jurnal Akuntansi Dan Manajemen, 7(2), 46-68.

Halim, A. (2015). Auditing: Dasar-dasar Audit Laporan Keuangan (Kelima). Yogyakarta: Unit Penerbitan dan Percetakan Sekolah Tinggi Ilmu Manajemen YKPN.

Hosseinniakani, Inacio, \& Mota. (2014). A Review on Audit Quality Factors. Intenational Journal of Academic Research in Accounting, Finance and Management Sciences, 4 (2), 243-254.

Kangarlouei, \& Jabbarzadeh, S. (2013). Independent Auditor Opini, Corporate Goverment and Financial Reporting Quality in Firms Listed in Tehran Stock Exchange. The SIJ Transactions on Industrial, FInancial \& Business Management (IFBM), 1 (2), 61-66.

Malone, C., \& Roberts. (1998). Factor Associated with the Incidence of Reduced Audit Quality Behaviors. Auditing: A Journal of Practice and Theory. Auditing A Journal of Practice and Theory, 15(2), 49-64.

Margheim, L., Kelly, \& Pattison, D. (2005). An Empirical Analysis of The Effects of Auditor Time Budget Pressure and Time Deadline Pressure. The Journal of Applied Business Research-Winter, 21(1).

Maryanti, P. (2005). Analisis Penerimaan Auditor atas Dysfunctional Audit Behavior: Pendekatan Karakteristik Personal Auditor (Studi Empiris pada Kantor Akuntan Publik di Jawa). Jurnal Maksi, 5(2), 213-226.

Nasrullah, D., Margono, \& Solimun. (2013). Professionalism and Locus Of Control Influence On Job Satisfaction Moderated By Spirituaity At Work And Its Impact 
ISSN: 2302-8556

E-Jurnal Akuntansi Universitas Udayana

Vol.25.3.Desember (2018): 1826 - 1855

On Perfomance Auditor. International Journal of Business and Management Invention, 2(10), 1-11.

Pitaloka, Y., \& Widanaputra. (2016). Integritas Auditor sebagai Pemoderasi Pengaruh Kompetensi dan Independensi pada Kualitas Audit. E-Jurnal Akuntansi Universitas Udayana, 16(2).

Prasita, A., \& Adi, P. H. (2007). Pengaruh Kompleksitas Audit dan Tekanan Anggaran Waktu terhadap Kualitas Audit dengan Moderasi Pemahaman. Jurnal Fakultas Ekonomi Dan Bisnis Universitas Kristen Satya Wacana, Semarang.

Pujaningrum, I., Sabeni, \& Arifin. (2012). Analisis Faktor-Faktor yang Mempengaruhi Tingkat Penerimaan Auditor Atas Penyimpangan Perilaku Dalam Audit. Diponegoro Journal of Accounting, 1(1), 1-15.

Samaei, L., Zahra, N. R., \& Semnani, A. S. H. (2012). Relationship between Locus of Control (Internal-External) and a Feeling of The Loneliness between Athletic and Non Athletic Girls. European Journal of Experimental Biology, 2(5).

Silaban, A. (2011). Pengaruh Multidimensi Komitmen Profesional terhadap Perilaku Audit Disfungsional. Jurnal Akuntansi Dan Auditing I, 8(1), 89-95.

Snead, K., \& Harrel. (1991). The Impact Of Psychological Factors on The Job Satisfaction of Senior Auditor. Behavioral Research in Accounting, 3, 85-96.

Sososutiksno, C. (2010). Perilaku Disfungsional Akibat Tekanan Anggaran Waktu (Studi Empiris di Lingkungan Badan Pengawasan Daerah Tingkat I dan Tingkat II Provinsi Maluku). Jurnal Maksi, 10(1), 89-95.

Srimindarti, C., Sunarto, \& Listyorini. (2015). The Effects of Locus of Control and Organizational Commitment to Acceptance of Dysfunctional Audit Behavior Based on the Theory of Planned Behavior. International Journal of Business, Economics and Law, 7(1), 27-35.

Sugiyono. (2014). Metode Penelitian Bisnis. Bandung: ALFABETA,CV.

Suprianto, E. (2009). Pengaruh Time Budget Pressure terhadap Perilaku Disfungsional Auditor (Audit Quality Reduction Behavior \& Underreporting of Time) (Studi Kasus pada Kantor Akuntan Publik di Jawa Tengah). Jurnal Akuntansi Indonesia, 5(1), 57-65. 
Widiarta. (2013). Pengaruh Gender, Umur, dan Kompleksitas Tugas pada Kualitas Audit Kantor Akuntan Publik di Bali. E-Jurnal Akuntansi Universitas Udayana, $3(1)$.

Winanda, H., \& Wirasedana. (2017). Pengaruh Tekanan Anggaran Waktu, Sifat Machiavellian, dan Kompleksitas Tugas Terhadap Perilaku Audit Disfungsional. E-Jurnal Akuntansi Universitas Udayana, 18(1).

Yuen, D. C. Y., Chan, \& Guan. (2013). Dysfunctional Auditing Behaviour: Empirical Evidence on Auditors Behaviour in Macau. International Journal of Accounting and Information Management, 21(3).

Yuliana, A., Herawati, \& Arum. (2009). Pengaruh Time Pressure dan Risiko Audit terhadap Penghentian Prematur atas Prosedur Audit. Jurnal Cakrawala Akuntansi, 1(1), 21-32. 